ZOOLOGIA 31 (6): 634-638, December, 2014

http://dx.doi.org/10.1590/S1984-46702014000600009

\title{
A new species of Avima, the first record of Agoristenidae (Opiliones: Laniatores) from the state of Roraima, Brazil
}

\author{
Willians Porto \& Pío A. Colmenares
}

Coordenação de Pesquisas em Biodiversidade, Instituto Nacional de Pesquisas da Amazônia. Avenida André Araújo 2936, Aleixo, Caixa Postal 478, 69011-970 Manaus, AM, Brazil.E-mail: willians.porto@outlook.com; pcolmenaresg@gmail.com

\begin{abstract}
We describe Avima anitas sp. nov. based on material collected in the Brazilian state of Roraima, representing the first record of Agoristenidae in the State. The new species differs externally from other species of Avima by presenting one proximal tubercle on the mesal face of the male cheliceral segment II and a pair of dark spots partially covering mesotergal area III-IV. The genital differs from other species by the ventral small setae of the ventral plate, which are trifid instead of uniramous or bifid.
\end{abstract}

KEY WORDS. Amazon Basin; harvestmen; Leiosteninae; Neotropical; taxonomy.

Agoristenidae is a Neotropical group of Laniatores distributed in the Greater Antilles and northern South America, with the southernmost record in Ecuador (KuRY 2003, 2012). The family is currently divided into three subfamilies, Agoristeninae Šilhavý, 1973, Leiostenindae Šilhavý, 1973, and Globibuninae Kury, 2012, grouping 24 genera and 72 species (KuRY 2003, Villarreal-M. \& Rodríguez-Manzanilla 2003, Pinto-DA-Rocha \& Hara 2009, Kury 2012). They are small gonyleptoidea that can be recognized in the field by having leg I filiform and short (normal but unarmed in Globibuninae) and legs II-IV without remarkable armature, the mesotergum divided into four areas (sometimes vestigial), and the cheliceral hand usually swollen in males. Even though they are normally litter dwellers, they can also be found inside logs, in roots of trees near the ground, under stones, even close to roads, and on walls of human residences. They are also common inhabitants of caves (RAMBLA 1978, GonZález-Sponga 1987, Pinto-Da-Rocha 1996).

Avima Roewer, 1949 comprises the major part of the family (33 species), with representatives in the Caribbean, Andean and Amazon regions (Kury 2003, 2013, Villarreal \& Kury 2009). The generic name has a complex history. It was considered synonymous with Trinella Goodnight \& Goodnight, 1947 by some authors, but was later restored by VILLARREAL \& KURY (2009), who detected a case of generic homonym (for more details see González-Sponga 1987, Pinto-da-Rocha 1996, Villarreal \& Kury 2009). Avima is more diverse in Venezuela (24 species), but it is also distributed in Brazil (3 species), Peru (2 species), Colombia (1 species), Suriname (1 species), and Trinidad \& Tobago (2 species) (Kury 2003, Villarreal-M. \& Rodríguez-Manzanilla 2003). Species of Avima can be quickly identified by the lack of spines or armature on mesotergal area III, having a dorsal scutum generally smooth or with fine tubercles (PINTO-DA-Rocha 1996, KuRY 1997), sometimes with stripes or spots, which may have bright colors - e.g., Avima venezuelica (Soares \& Avram, 1981). In this paper a new species of Avima is described, representing the first record of the family in the Brazilian state of Roraima.

\section{MATERIAL AND METHODS}

The type material is deposited in the Instituto Nacional de Pesquisas da Amazonia (INPA). The description follows AcosTA et al. (2007) and measurements are given in millimeters. The acronyms for the measurements generally follow PINTO-DA-RochA $\&$ Tourinho (2012): (DSL) dorsal scutum length, (PL) prosomal length, (DSW) dorsal scutum maximal width, (PW) maximum prosomal width, (ID) interocular distance, $(\mathrm{MH})$ maximum height. Acronyms for repository institutions is: (INPA) Instituto Nacional de Pesquisas da Amazônia, Manaus, Brazil.

We drew the male paratype to avoid damaging the holotype. To make the drawings we used a camera lucida attached to a Leica M80 stereoscope (external morphology) and a Leica DM500 compound microscope (genital morphology). Pictures and measurements were taken with an automated stereomicroscope Leica M205C system, a DFC295 Leica camera, and dedicated software Leica Application Suite version 4.0.0 (Leica 2003-2011).

\section{TAXONOMY}

\section{Avima anitas sp. nov. \\ Figs 1-9}

Diagnosis. Differs from other species of Avima by the combination of the following characters: one proximal tubercle on the mesal face of the male's cheliceral segment II (Fig. 3), a pair of dark spots partially covering mesotergal areas III-IV (Figs 1 and 3), ventral small setae of ventral plate of penis trifid, instead of simple or bifid (Figs 6 and 7). 

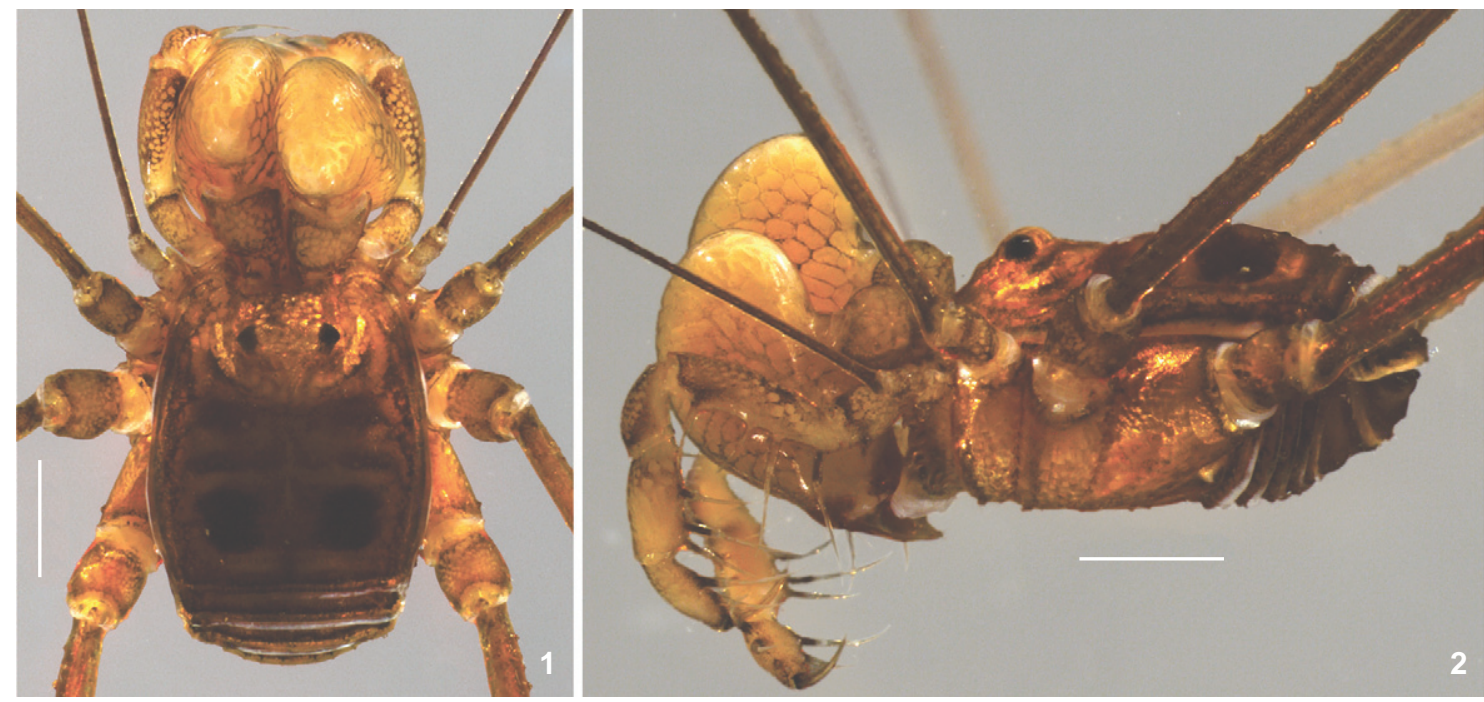

Figures 1-2. Habitus of Avima anitas sp. nov., male holotype (INPA-OP 3399): (1) dorsal view; (2) Lateral view. Scale bars: 1 mm.

Description. Male (Holotype INPA-OP 3399). Measurements: DSL: $3.35 \mathrm{~mm}$, SML: $2.77 \mathrm{~mm}$, PL: $1.20 \mathrm{~mm}$, DSW: 2.45 mm, PW: 2.28 mm, ID: 0.57 mm, MH: 1.99 mm. Dorsum (Figs 1-3): Prosoma with anterior margin smooth; cheliceral sockets not too deep; with 3-4 small tubercles on each side; ocularium placed centrally, more or less the same height of abdomen in lateral view (Fig. 2). Opisthosoma wider at area II; groove I well marked, all remaining grooves almost vestigial; area I-II with 4-5 small tubercles on each side, III-IV with a pair of small paramedian tubercles; posterior margin and free tergites with a row of small tubercles; anal operculum finely tuberculated. Venter: Coxa I with anterior bifid tubercle and median row with six conical tubercles; II-III with two rows of tubercles; IV covered with 3-4 rows of tubercles. Genital operculum finely tuberculated. Free sternites with row of small tubercles. Chelicerae (Figs 3 and 4): Segment I with well-marked bulla, one dorsal, two lateral and three posterior tubercles. Segment II swollen, with proximal tubercle on mesal surface (Fig. 3), three frontal setiferous tubercles (almost in mesal position), and some sparse distal setae (Fig. 4); fixed finger with a serrated hump on mid portion (Fig. 4). Segment III (movable finger) with basal, strong tooth and distally serrated hump followed by row of small teeth (Fig. 4). Pedipalp (Fig. 5): Trochanter ventrally with two subapical tubercles. Femur ventrally with five setiferous tubercles, two meso-proximal, one medial, one meso-distal and one ecto-distal. Patella with large mesal setiferous tubercle. Tibia ectal iIIi, mesal IIi. Tarsus ectal IIi, mesal IIi. Legs: Coxa I with two dorsal tubercles; II with one antero-dorsal tubercle and one small posterior tubercle, fused with one small tubercle of III; IV with 2-3 distal tubercles. Femora with rows of small tubercles. Entire patella to tibia with rows of fine granules. Tarsal formula: 8(3)/14(3)/6-7/7. Penis (Figs 6-9): Ventral plate pro- jected latero-dorsally, mid portion thick and getting thinner towards margins, which have ear-like shape in dorsal and ventral views (Figs 6 and 8). Three groups of setae: four pairs of trifid setae on truncus, from proximal dorso-lateral position to ventro-distal position; two pairs of acuminate small setae close to the basis of the stylus (Figs 6 and 7); one pair of apical small and truncate trifid setae on ventral side of the ventral plate (Figs 7 and 8). Stylus with dorsal keel (Figs 6 and 7) with distal border;serrated; apex slightly bent dorsally. Color (in alcohol, Figs 1 and 2): Holotype and two paratypes yellowish to light brown, with two darker spots covering mesotergal areas III-IV. Variation: in the paratype the dark spots on mesotergum reach the posterior portion of area II. The tubercles on the lateral portions of the prosoma are vestigial.

Female (Paratype INPA-OP 3417). Measurements: DSL: $3.17 \mathrm{~mm}$, SML: $2.54 \mathrm{~mm}$, PL: $0.98 \mathrm{~mm}$, DSW: $2.15 \mathrm{~mm}$, PW: $1.93 \mathrm{~mm}$, ID: $0.42 \mathrm{~mm}, \mathrm{MH}: 1.77 \mathrm{~mm}$. Slightly smaller than male. Body, pedipalps and color as in the male. Chelicera not swollen, without the proximal tubercle on the mesal face. Tarsal formula: 8-7(3)/14(3)/7/7.

Type material. Holotype, male (INPA-OP 3399), BRAzIL, Roraima: Serra do Tepequém, S. Bogão leg., 03.vi.2011. Paratypes. One male (INPA-OP 3418), BrAzIL, Roraima: Amajari (ESEC Maracá L210-250), Jarbas leg., 03.v.2009. Two females (INPA-OP 3417, and INPA-OP 3419), same data as holotype.

Distribution (Fig. 10). The type material comes from two locations in the north of the state of Roraima: Serra do Tepequém (holotype and two paratypes) and Estação Ecológica de Maracá (one paratype).

Etymology. This species is named after the arachnologist Ana Lúcia Tourinho. She is the leader of a project on amazonian arachnids, which focuses on harvestmen."Anitas" is her nickname. 

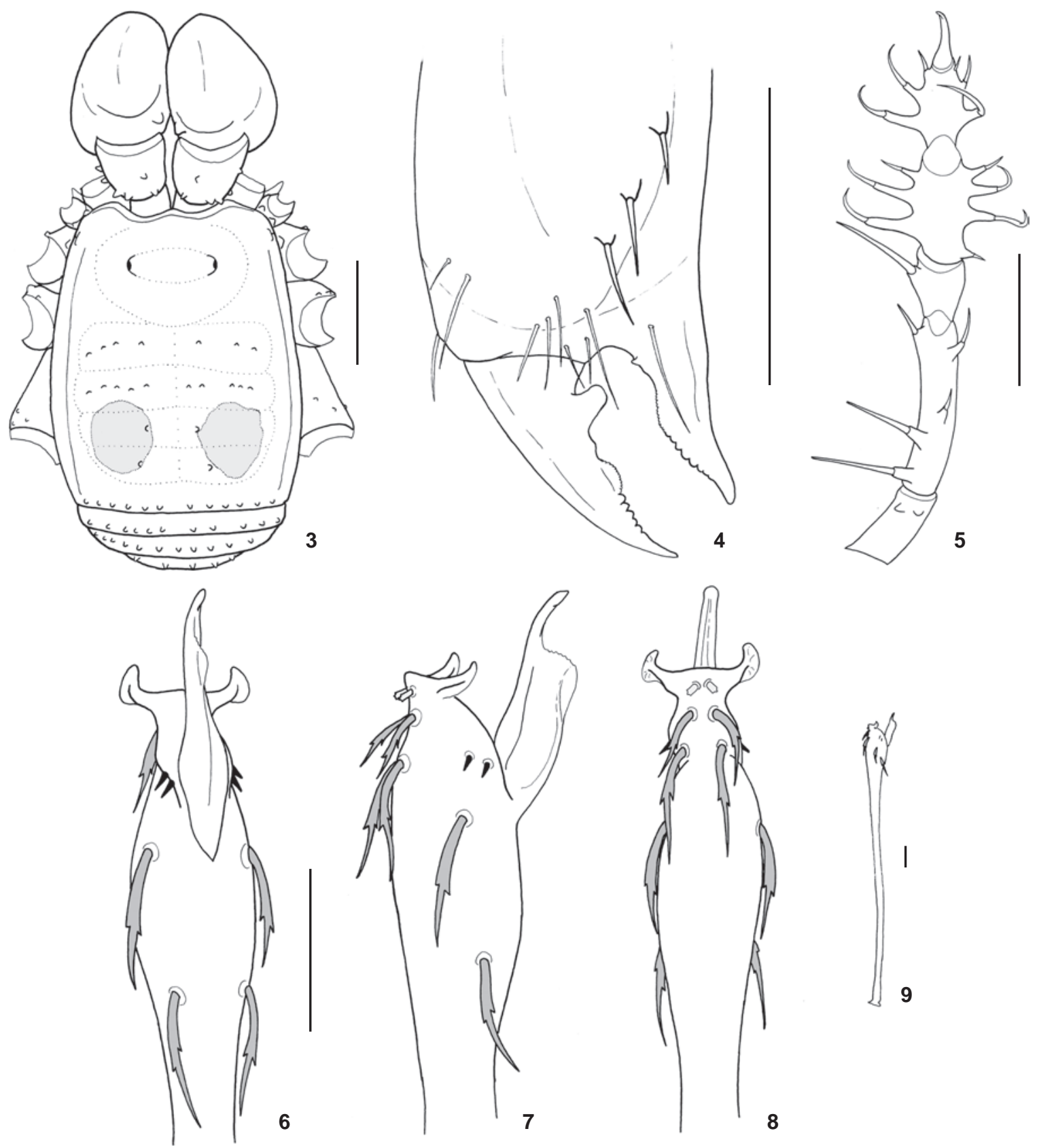

Figures 3-9. Avima anitas sp. nov., male paratype (INPA-OP 3418): (3) habitus, dorsal view; (4) distal portion of male chelicerae; (5) left pedipalp, ventral view; (6-9) penis: (6) dorsal view; (7) lateral view; (8) ventral view; (9) complete lateral view. Scale bars: $3-5=1 \mathrm{~mm}$, $6-9=0.1 \mathrm{~mm}$.

Remarks. The dorsal scutum of Avima anitas sp. nov. is larger when compared to Avima matintaperera (Pinto-da-Rocha 1996), Avima soaresorum (Pinto-da-Rocha, 1996), and Avima bicoloripes Roewer, 1949, the other Brazilian species. The number of tubercles on mesotergal areas I-IV is also different in the new species, being $\mathrm{I}(8-10), \mathrm{II}(10), \mathrm{III}(2)$ and $\mathrm{IV}(2)$ in $A$. anitas sp. nov. instead of I(4), II(4), III(4) and IV(4) of A. matintaperera, and I(4), II(6), III(6) and IV(6) of A. soaresorum; following Roewer's description, $A$. bicoloripes has rows of transversal granules on mesotergal areas. 


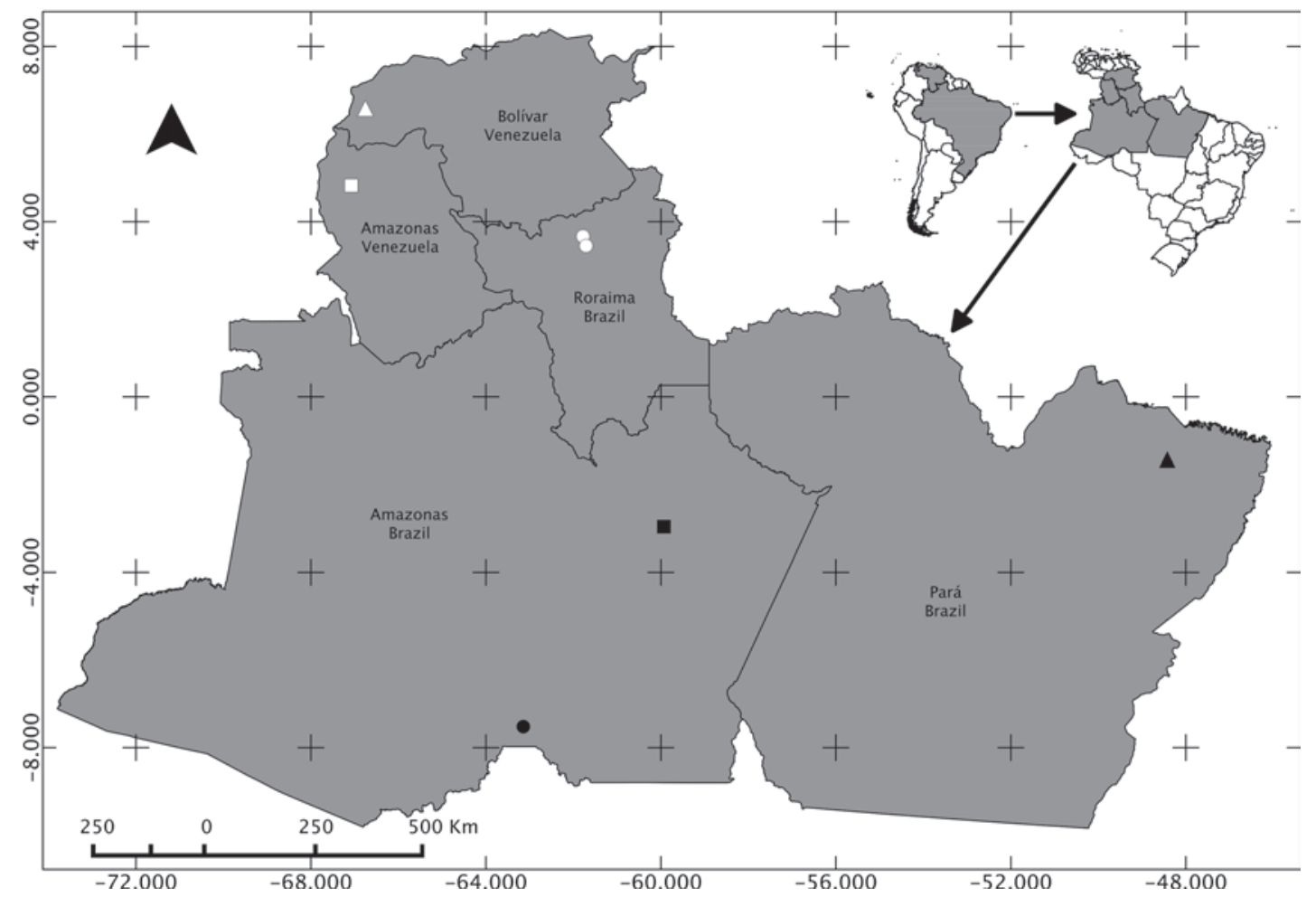

Figure 10. Map showing the distribution of Avima anitas sp. nov. $(\bigcirc)$ and the geographically nearest species: $A$. albimaculata $(\triangle)$, A. glabrata $(\square)$, A. matintaperera $(\square)$, A. soaresorum $(\mathbf{0})$ and A. bicoloripes $(\mathbf{\Delta})$.

\section{DISCUSSION}

The only two published cladistic analyses of Agoristenidae were conducted to evaluate suprageneric relationships (KURY 1997, PINTO-DA-Rocha \& Hara 2009), without formulating a hypothesis for the relationships within Avima. That makes it difficult to ascertain the relationships of $A$. anitas sp. nov. with the remaining species. However, after comparing among species we were able to find similarities that can be tested in the future.

The general genital chaetotaxy of Avima seems to be arranged in three groups: four pairs of trifid setae on the truncus that may vary in their position (the apical pair can sometimes be on the ventral plate), one to three pairs of simple setae close to the basis of the stylus and one pair of small ventro-apical setae on the ventral plate - e.g., Avima chiguarensis (GonzálezSponga, 1987), Avima falconensis (González-Sponga, 1987) -, which is sometimes absent (e.g., A. matintaperera, A. soaresorum). The ventral plate is projected laterally and can be u-shaped; the stylus has a dorsal keel in some specimens. This pattern occurs in A. anitas sp. nov. In this species, all setae are present, but there is one main difference from the other species: the ventro-apical setae on the ventral plate, are trifid, instead of uniramous or bifid. Furthermore, the margins of the ventral plate are flat, slightly membranous and rounded, ear-shaped, and are somewhat similar to the ventral plate of Vima insignis Hirst, 1912, as shown in PINTO-DA-Rocha (1996). The stylus has a moderate dorsal keel, present in at least one other Amazonian species, $A$. matintaperera, which is also the geographically closest Brazilian species.

We examined diagnoses, descriptions, and illustrations of the all species of Avima, looking for tubercles on the mesal surface of male cheliceral segment II, but we did not find it; this feature distinguishes $A$. anitas sp. nov. from all remaining species.

Avima anitas sp. nov. resembles some Venezuelan species by having spots or patches on mesotergal areas. Species such as Avima albidecorata (Silhavyì, 1979), Avima albimaculata (Gonzaìlez-Sponga, 1998), Avima nigromaculata (GonzaìlezSponga, 1998), Avima quirozi (Gonzaìlez-Sponga, 1987), Avima subparamera (Gonzaìlez-Sponga, 1987) and A. venezuelica exhibit different kinds of spots, from one circular or one irregular to two spots in different regions of the dorsal scutum, but the new species is the only one with those spots on areas II-IV. Among the Amazonian species, A. albimaculata and Avima glabrata (Gonzailez-Sponga, 1998) are geographically the closest taxa, and they could be closer to A. anitas sp. nov. than other Amazonian species, based on the lack of ornamentation on the ocularium and pedipalpal tibia with four ectal spiniform 
tubercles. The genital morphology of $A$. anitas sp. nov. may also indicate phylogenetic affinity with $A$. albimaculata and $A$. glabrata, since these three species share a similar shape of the ventral plate, and the styles of all of them have a dorsal keel. Beyond that, it is difficult to make more accurate comparisons between A. albimaculata, A. glabrata, and the new species, because the drawings of GonzÁLEz-Sponga (1998) are not detailed enough and he did not describe the genitalias.

Despite the great landscape diversity of the Amazonian state of Roraima, which has elements from the Amazon and the Guiana Shield, its opilionid fauna is still poorly known. There are only two publications describing six species from Roraima: Goodnight \& Goodnight (1943), described four stygnids and one sclerosomatid, and Roewer (1943) described one zalmoxid. A summary of the species from Roraima can be found in Kury \& PINTO-DA-Rocha (2002) and Kury (2003). Avima anitas sp. nov. represents the first record of the family in Roraima, and at the same time fills a gap in the distribution of the genus, which has species in the southern Venezuelan states of Amazonas (A. glabrata) and Bolivar (A. albimaculata) and in the northern Brazilian states of Amazonas (A. matintaperera, A. soaresorum) and Pará (A. bicoloripes) (Fig. 10).

\section{ACKNOWLEDGEMENTS}

Pío A. Colmenares would like to thank Aqua Quest ${ }^{\circledR}$ for supplying waterproof equipment during his work in the Amazon. This study was supported by The Coordination of Improvement of Higher Education Personnel (CAPES, PEC-PG scholarship\#5828104 to P.A. Colmenares), Conselho Nacional de Desenvolvimento Científico e Tecnológico (CNPq, grant\#383266/2013-0 to W. Porto), and Programa de Pesquisa em Biodiversidade - PPBio.

\section{LITERATURE CITED}

AcostA L.E.; A.B. KuRY \& M.L. JuÁREZ. 2007. New records of Geraeocormobius sylvarum (Arachnida, Opiliones, Gonyleptidae), with a remarkable disjunction in northwestern Argentina. Boletín de la Sociedad Entomológica Aragonesa, 41, 303-306. doi:10.1636/T07-36.1

GonZÁlez-SPONGA, M.A. 1987. Arácnidos de Venezuela. Opiliones Laniatores I. Familias Phalangodidae y Agoristenidae. Caracas, Academia de Ciencias Físicas, Matemáticas y Naturales, 562p.
GonzÁlez-Sponga, M.A. 1998. Arácnidos de Venezuela. Cuatro nuevas especie de la familia Agoristenidae (Opiliones: Laniatores). Acta Biológica Venezuélica 8 (3): 21-33.

Goodnight, C.J. \& M.L. Goodnight. 1943. Phalangida from South America. American Museum Novitates 1234: 1-19

KurY, A.B. 1997. A new subfamily of Agoristenidae, with comments on suprageneric relationships of the family (Arachnida, Opiliones, Laniatores). Tropical Zoology 10 (2): 333-346. doi: 10.1080/03946975.1997.10539346

KuRY, A.B. 2003. Annotated catalogue of the Laniatores of the New World (Arachnida, Opiliones). Revista Ibérica de Aracnología 1:, 1-337.

KuRY, A.B. 2012. First report of the male of Zamora granulata Roewer 1928, with implications on the higher taxonomy of the Zamorinae (Opiliones, Laniatores, Cranaidae). Zootaxa 3546: $29-42$.

KunY, A.B. 2013. Classification of Opiliones. Available online at: http://www.museunacional.ufrj.br/mndi/Aracnologia/ opiliones.html [Accessed: 22/VII/2014]

Kury, A.B. \& R. Pinto-DA-Rocha. 2002. Opiliones, p. 345-362. In: J. Adis (Ed.). Amazonian Arachnida and Diplopoda - Keys for the identification to classes, orders, families, some genera, and lists of known species. Sofia-Moscow, Pensoft Publishers, 589p.

PinTo-DA-Rocha, R. 1996. Notes on Vima insignis Hirst, 1912, revalidation of Trinella Goodnight \& Goodnight, 1947 with description of three new species (Arachnida, Opiliones, Agoristenidae). Revista Brasileira de Entomologia 40 (2): 315-323.

Pinto-Da-Rocha, R. \& M.R. Hara. 2009. New familial assignments for three species of Neotropical harvestmen based on cladistic analysis (Arachnida: Opiliones: Laniatores). Zootaxa 2241: 33-46.

Pinto-DA-Rocha, R. \& A.L. Tourinho. 2012 Two new genera, ten new species and new records of Amazonian Stygnidae Simon, 1879 (Opiliones: Laniatores). Zootaxa 3340: 1-28.

Rambla, M. 1978. Opiliones cavernicolas de Venezuela (Arachnida, Opiliones Laniatores). Speleon 24: 5-22.

Roewer, C.F. 1943. Über Gonyleptiden. Weitere Weberknechte (Arachn., Opil.) XI. Senckenbergiana 26 (1-3): 12-68.

Villarreal-M., O. \& A.B. Kury. 2009. A new generic homonym in the Agoristenidae (Arachnida: Opiliones). Zootaxa 2045: 65-68.

Villarreal-M., O. \& C.J. Rodríguez-Manzanilla. 2003. Descripción de Trinella vigirima sp. nov. (Opiliones: Agoristenidae) de Venezuela. Entomotropica 18 (3): 177-182.

Submitted: 26.VII.2014; Accepted: 01.XII.2014.

Editorial responsibility: Antonio D. Brescovit

ZOOLOGIA 31 (6): 634-638, December, 2014 